\title{
POLA MAKAN DAN GEJALA ANEMIA PADA MAHASISWA PERANTAUAN DI UNIVERSITAS SAMUDRA
}

\section{EATING PATTERN AND ANEMIA SYMTOMS IN STUDENTS OF OVERSEAS IN SAMUDRA UNIVERCITY}

\section{Nurul Aulia Mufa ${ }^{1}$, Syafani Syarifah $^{2}$, Suci Hidayani Putri ${ }^{3}$, Ameliyani $^{4}$, Sri jayanthi ${ }^{5}$}

Fakultas Keguruan Dan Ilmu Pendidikan Biologi Universitas Samudra, Langsa, Indonesia. (nurulauliamufa88@gmail.com)

\begin{abstract}
ABSTRAK
Pola makan ialah perilaku yang mempengaruhi gizi. Kualitas dan kuantitas makanan dan minuman yang dikonsumsi akan mempengaruhi kesehatan. Hal ini yang menyebabkan kekurangan gizi pola makan yang sehat dan seimbang sangat dibutuhkan untuk mendukung kelancaran aktivitas keseharian yang padat misalnya mahasiswa perantauan. Tujuan penelitian ini untuk melihat pengaruh pola makan dengan gejala anemia pada masahasiwa perantauan. Metode yang digunakan ialah deskriptif yaitu dengan mengisi angket di google form yang terdapat 70 responden. Hasil dari penelitian ini 50 orang $74,3 \%$ merasakan adanya gejala anemia 20 oranf $25,7 \%$ tidak merasakan vejala anemia. Hal yang harus dilakukan agar tidak terjadinya anemia harus ada perubahan pola makan.
\end{abstract}

Kata kunci : Pola makan, mahasiswa perantauan, gejala anemia.

\section{ABSTRACT}

Diet is a behavior that affects nutrition. The quality and quantity of food and beverages consumed will affect health. This causes nutritional deficiencies, a healthy and balanced diet is needed to support the smooth running of busy daily activities, such as overseas students. The purpose of this study was to examine the effect of diet with symptoms of anemia in overseas students. The method used is descriptive, namely by filling out a questionnaire on google form which contains 70 respondents. The results of this study 50 people $74.3 \%$ felt the symptoms of anemia 20 or $25.7 \%$ did not feel the symptoms of anemia. The thing that must be done so that anemia does not occur must be a change in diet.

Keywords : Dietary habit, student of overseas and Anemi symtoms.

\section{PENDAHULUAN}

Pola makan ialah perilaku yang mempengaruhi gizi. Kualitas dan kuantitas makanan dan minuman yang dikonsumsi akan mempengaruhi kesehatan. Hal ini yang menyebabkan kekurangan gizi pola makan yang sehat dan seimbang sangat dibutuhkan untuk mendukung kelancaran aktivitas keseharian yang padat misalnya mahasiswa perantauan.

Mahasiawa ialah kelompok usia peralihan dari masa remaja menjadi dewasa. Pada pola makan di masa peralihan perlu di perhatikan agar tidak terjadi gangguan kesehatan. Salah satu ganguan kesehatan yang disebabkan pola makan yang tidak teratur ialah anemia. Anemia merupakan salah satu masalah kesehatan yang masih menyerang Indonesia. Tanpa mengenal batas usia dan jenis kelamin anemia dapat diderita oleh siapapun tanpa disadari.

Anemia didefenisikan suatu keadaan kadar Hemoglobin $(\mathrm{Hb})$ di dalam darah lebih rendah dari pada nilai normal untuk kelompk umur dan jenis kelamin (Merryana Adriani, 2015 ). Penyebab anemia paling umum terjadi adalah defisiensi zat besi. Kehilangan darah yang menetap akibat penyakit infeksi akut dan kronis (diare, malaria, HIV).

Gejala anemia meningkat karena mahasiswa perantauan memiliki kebiasaan makan yang kurang baik yaitu tidak 
mengkonsumsi sayur san buah secara rutin, tidak sarapan dengan teratur dan mengkonsumsi makanan intastan dan cepat saji karena lebih praktis dan lebih efisien karena hampir rata-rata mahasiswa perantauan tinggal di kost-kostan. Mahasiswa perantauan memiliki pola makan yang tidak teratur karena tidak tinggal dengan orang tua. Hal lain mengakibatkam mahasiawa perntauan kurang memperhatikan pola makan yaitu aktivitas yang padat di kampus, kesulitan ekonomi, kurang pengetahuan dan kepedulian dan pengetahuan terhadap pola makan yang baik dan benar dari banyak survey yang telah banyak peneliti sebelum nya melakukannya mereka menyebytkan bahwa mahasiswa mempunyai pola makan yang tidak baik di karenakan kesibukan tugas dan aktivitas lainnya keba yakan mahasiswa mengkonsumsi makanan yang tidak seimbang seperti makanan cepat saji selain itu banyak mahasiswa yang mengabaikan srapan pagi dengan alas an tidak cukup waktu untuk makan pagi, dan banyak pula mahasiswa yang kutrang mengkonsumsi sayur-sayuran hal ini di akibatkan oleh bebrapa factor seperi aktivitas yang padat,ekonomi yang kurang,aktivitas kuliah yang padat dan lain sebagainya oleh karena uraian diatas penelitian bertujuan menganalisis pengaruh pola makan dengan gejala anemia pada masiswa perantauan pola makan makan mahasiswa menjadi suatu hal utama peniliti untuk melihat gejala anemia yang di rasakan oleh mahasiswa, dimana subyek dari penelitian ini adalah mahasiswa universitas samudra
Jurnal Jeumpa, 7 (2) Juli-Desember 2020 METODELOGI PENELITIAN

Penelitian ini dilakukan bulan april 2021 di Universitas Samudra, Kota Langsa, Aceh, Indonesia. Populasi pada penelitian ini ialah mahasiswa perantauan Universitas Samudra. Sampel diambil menggunakan google form yang disebarkan ke social media yang diisi oleh 70 responden. Data yang diperoleh melalui angket melalui google form untuk melihat bagaimana pola makan mahasiswa, apa saja yang di konsumsi mahasiswa untuk di makan, melihat jadwal-jadwal makan dan keterlambatan makan mahasiswa, gejalagejala yang di alami mahasiswa ketika terlambat makan, dll dan metode analisis yang digunakan ialah secara deskriptif. Penelitian ini dapat dilakuakn lebih lanjut oleh bidang ahli seperti dalam bidang kesehatan.

\section{HASIL PENELITIAN}

Hasil dari penelitian yaitu antara pola makan dengan gejala anemia diketahui sebanyak 70 orang dan sebagian banyak responden berumur 21 tahun yaitu sebanyak 40 responden dan yang berumur 21 tahun ke atas sebanyak 30 0rang responden dari hasil analisis penelitian yang di lakukan bahwa sebagian besar dari responden mengalami gejala anemia yang di sebabkan oleh pola makan yang tidak teratur pola makan yang tidak teratur dari 70 responden yang di teliti Sebanyak 50 orang merasakan gejala anemia 74,3\%, 20 tidak merasakan gejala anemia 25,7\%. Dari kejadian anemia tersebut terlihat ada beberapa siswa yang pola makannya kurang teratur tetapi tidak menimbulkan gejala anemia yaitu sebanyak 8 orang dan sebanyak 20 orang yang pola 
makan tidak teratur sehingga menimbulkan gejala anemia. Hasil ini dapat di simpulkan bahwa pola makan yang tidak teratur lebih mudah terserang penyakit anemia dibandingkan dengan pola makan yang teratur

\section{PEMBAHASAN}

Mahasiswa merupakan kelompok remaja yang sedang menempuh pendidikan yang lebih tinggi dimana pada masa ini lah mahasiswa membutuhkan pola makan yang sehat dan teratur. Tetapi banyak mahasiswa yang mengabaikan pola makannya karena kesibukan diri masing-masing sehingga pola makan menjadi tidak teratur, semnatra untuk memulai hari-hari dfan aktivitasnya membutuhkan pola makan yang seimbang agar dapat lebor berenergi dan jauh dqari serangan penyakit.

Pada penelitian ini memperlihatkan bahwa Pola makan yang seimbang sangat berpengaruh terhadap gejala anemia yaitu dengan melihat dari presentasi $74,3 \%$ merasakan adanya gejala anemia sedangkan $25,7 \%$ tidak merasakan gejala anemia dari 70 responden yang di teliti. Hal ini dilihat dari pertanyaan yang diajukan dimana mahasiswa perantauan tidak sarapan pagi dengan tepat waktu, tidak menerapkan pola makan yang baik. Menu sarapan yang di makan setiap pagi juga lebih besar karbohidrat dan seringnyamengkonsumsi makan instan dan cepat saji serta banyak dari responden mahasiswa perantauan yang buah atau sayur setiap hari, tidak mengkonsumsi air 2,5 liter sehari nya. Pola makan yang telat juga sering terjadi karena banyaknya kegiatan yang dilakukan oleh mahasiswa yaitu tugas yang banyak dan kegiatan yang
Jurnal Jeumpa, 7 (2) Juli-Desember 2020 dilakukan setelah kegiatan belajar. Aktifitas yang banyak tidak diimbangi dengan pola makan yang baik dimana sarapan pagi dan pola makan lainnya tidak dilakukan secara teratur sehingga selama beraktifitas mahasiswa sering merasakan lemas karena pola makan yang berantakan. Faktor gizi merupakan salah satu penyebab kejadian anemia. Faktor gizi terkait dengan defisiensi protein, vitamin dan mineral. Protein berperan dalam proses pembentukan hemoglobin, dalam jangka waktu lama tubuh kekurangan protein menyebabkan terganggunya pembentukan sel darah merah, sehingga menyebabkan timbulnya gejala anemia.

Kurangnya mengkonsumsi protein dapat menyebabkan terjadinya anemia. Sumber protein hewani merupakan sumber zat besi heme. Heme lebih mudah penyerapan dibanding dengan non heme. Zat yang dapat menghambat penyerapan besi atau inhibitor antara lain adalah kafein, tanin, oksalat, fitat yang terdapat dalam produk-produk kacang kedelai, teh dan kopi. Karena masih tingginya gejala responde yang merasakan anemia karena pola makan yang tidak seimbang, diharapkan kepada masiswa persntauan untuk merubah pola makan yang baik dan teratur dengan mengkonsumsi makanan yang mengandung protein, zat besi. Serta mengurangi mengkonsumsi makanan instan dan cepat saji.

\section{KESIMPULAN DAN SARAN}

Mahasiswa yang benrpengaruh dengan pola makan dengan merasakan gejala anemia ialah $74,3 \%$ yaitu 50 orang dan yang tidak merasakan gejala anemia 20 
atau $25,7 \%$. Hal ini menunjukan pola makan

sangat berpengaruh terdahadap gejala anemia dimana dapat mengganggu aktifitas yang dilakuakan yaitu terasa lemas, hal ini dapat diatasi dengan mengkonsumsi makanan yang berprotein baik nabati ataupun hewani perubahan pola makan dan mengurangi makanan cepat saji dan instan.

\section{DAFTAR PUSTAKA}

Adriana Merryana, SKM,M.Kes. dan Wirjadmadi Bambang, M.S. MCN,. PHD. 2012. Pengantar Gizi

Masyarakat. Kencana. Jakarta.

Gunatmaningsih, Dian. 2007. Faktor-

Faktor Yang Berhubungan Dengan
Jurnal Jeumpa, 7 (2) Juli-Desember 2020 Anemia Pada Remaja Putri. Skripsi. Universitas Negeri Semarang .

Masthalina H, Laraeni Y, Putri Y, et al. Pola Konsumsi (Faktor Inhibitor Dan Fe) terhadap status anemia remaja putri. J Enhancer $\mathrm{Fe}$ ) Terhadap Status Anemia Remaja Putri. Kemas. 2015;11(1):80-86. 6.

Suryani D, Hafiani R, Junita R. Analisis Pola Makan dan Anemia Gizi Besi Pada Remaja Putri Kota Bengkulu. $J$ Kesehat Masy Andalas. 2015;10:1118.

Yuni, Natalia Erlina . 2017. Kelainan Darah. Nuha Medika.Yogyakarta 